\title{
Genotoxicity assessment of a pharmaceutical effluent using four bioassays
}

\author{
Adekunle A. Bakare ${ }^{1}$, Alabi A. Okunola ${ }^{2}$, Olusanmi A. Adetunji ${ }^{1}$ and Hafeez B. Jenmi ${ }^{1}$ \\ ${ }^{1}$ Cell Biology and Genetics Unit, Department of Zoology, University of Ibadan, Oyo State, Nigeria. \\ ${ }^{2}$ Department of Basic \& Applied Science, Babcock University, Ogun State, Nigeria.
}

\begin{abstract}
Pharmaceutical industries are among the major contributors to industrial waste. Their effluents when wrongly handled and disposed of endanger both human and environmental health. In this study, we investigated the potential genotoxicity of a pharmaceutical effluent, by using the Allium cepa, mouse- sperm morphology, bone marrow chromosome aberration (CA) and micronucleus (MN) assays. Some of the physico-chemical properties of the effluent were also determined. The $A$. cepa and the animal assays were respectively carried out at concentrations of $0.5,1$, $2.5,5$ and $10 \%$; and $1,5,10,25$ and $50 \%$ of the effluent. There was a statistically different $(p<0.05)$, concentration-dependent inhibition of onion root growth and mitotic index, and induction of chromosomal aberrations in the onion and mouse CA test. Assessment of sperm shape showed that the fraction of the sperm that was abnormal in shape was significantly $(p<0.05)$ greater than the negative control value. MN analysis showed a dose-dependent induction of micronucleated polychromatic erythrocytes across the treatment groups. These observations were provoked by the toxic and genotoxic constituents present in test samples. The tested pharmaceutical effluent is a potentially genotoxic agent and germ cell mutagen, and may induce adverse health effects in exposed individuals.
\end{abstract}

Key words: genotoxicity, pharmaceutical effluent, mouse, Allium cepa, chromosome, spermatozoa, micronucleus.

Received: September 16, 2008; Accepted: January 22, 2009.

\section{Introduction}

Pharmaceuticals are produced and used in increasingly larger amounts every year, this having caused the industry to become one of the major contributors to industrial waste. Generally, pharmaceutical industries do not generate uniform waste streams, due to the variety of medicines produced during any given processing period (Houk, 1992). In recent times, a wide range of pharmaceuticals have been found in fresh and marine waters, and it has been shown that even in reduced quantities, some of these compounds are potentially capable of causing harm to both aquatic and terrestrial life forms (Jonathan and Nicolaos, 2005). The presence of pharmaceutical chemicals in the environment is a matter of concern due to their lipophilic and non-biodegradability nature, as well as their biological activities (Velagaleti and Burns, 2006). Currently, there is scarce of measurable evidence of the environmental impact of pharmaceutical chemicals on human health (Christensen, 1998).

A review of studies using microbial assays has shown that pharmaceutical waste does not appear to be particularly mutagenic, although it may be genotoxic by other

Send correspondence to Adekunle. A. Bakare. Cell Biology and Genetics Unit, Department of Zoology, University of Ibadan, Oyo State, Nigeria. E-mail: adekunle.bakare@mail.ui.edu.ng, adebakar19@yahoo.com. mechanisms (McGeorge et al., 1985; Moller et al., 1985; Houk and DeMarini, 1988; Sanchez et al., 1988). Houk (1992) suggested that, even though there is no specific evidence to suggest this, the chemical composition of pharmaceutical waste may make it unsuitable for microbial assays, since it could contain antibiotics or bacterial growth inhibitors. Thus, to be able to arrive at sufficient conclusions on the potentially genotoxic, mutagenic and masking effects of pharmaceutical waste constituents, it is important that other test systems be utilized, and also chemical characterization carried out on this group of wastes. In the present study, four eukaryotic mutagenicity assays, namely the Allium cepa assay, the mouse sperm morphology assay, the micronucleus ( $\mathrm{MN})$ test and the chromosome aberration (CA) assay in mouse bone marrow cells, were used to evaluate the genotoxic and mutagenic potential of effluents from a pharmaceutical company. These are the standard bioassays that best reflect the delicate balance between pathways for activation and inactivation of chemicals in human beings.

\section{Materials and Methods}

\section{Effluent collection}

The raw effluent from a pharmaceutical plant in Lagos State, Nigeria was collected in two $10 \mathrm{~L}$ plastic containers, from the point of discharge into the environment. 
The company produces analgesics, anti-malarias, anesthetics, multivitamins, antibiotics, antihistamines, human vaccines, sulphonamides and antiemetics. The collected material was filtered and the $\mathrm{pH}$ taken, to be then kept at $4{ }^{\circ} \mathrm{C}$ until use.

\section{Biological materials}

Onions (Allium cepa, L., $2 \mathrm{n}=16$, Family Amaryllidaceae), obtained commercially at the Bodija market, Ibadan, Nigeria, were sun-dried for 2 weeks. The dry bulbs, rotten ones excluded, were later used for the test. Young male Swiss albino mice (Mus musculus) of 6-10 weeks old, which had been inbred for several generations, were obtained from the animal breeding unit of the Department of Physiology, University of Ibadan, Nigeria. They were kept in a pathogen free, well ventilated animal house at the Department of Zoology, University of Ibadan, for 2 weeks in order to acclimatize. They were maintained in the same room throughout the period of this study. Food (Ladokun pelleted feed $\AA$ ) and drinking water were supplied ad libitum. The mice were divided into 3 categories for animal assays: the CA assay and $\mathrm{MN}$ test for mice 8 weeks old, and the sperm morphology assay for mice 12-14 weeks old.

\section{Physico-chemical properties and heavy metal analysis}

The effluent was analyzed for a number of standard physico-chemical properties, including chemical oxygen demand (COD), total dissolved solids (TDS), alkalinity, biochemical oxygen demand (BOD), chlorides, nitrates, ammonia and phosphates, according to methods described by APHA (1998). Nine metals (including eight heavy metals) namely aluminum $(\mathrm{Al})$, cadmium $(\mathrm{Cd})$, copper $(\mathrm{Cu})$, chromium $(\mathrm{Cr})$, iron $(\mathrm{Fe})$, mercury $(\mathrm{Hg})$, zinc $(\mathrm{Zn})$, nickel (Ni) and manganese (Mn) were analyzed in the effluent sample according to standard analytical methods (USEPA, 1996; APHA, 1998). Briefly, $100 \mathrm{~mL}$ of the effluent was digested by heating with concentrated $\mathrm{HNO}_{3}$, and the volume reduced to $3-5 \mathrm{~mL}$. This volume was made up to $10 \mathrm{~mL}$ with $0.1 \mathrm{~N} \mathrm{HNO}_{3}$. Concentrations of the metals were estimated by using an Atomic Absorption Spectrophotometer (Perkin Eelmer E. Analyst, 2000, USA).

\section{Allium cepa test}

The modified A. cepa assay (Fiskesjo, 1997; Bakare and Wale-Adeyemo, 2004; Babatunde and Bakare, 2006) was employed in this study. The outer scales of the onion bulbs and any brownish bottom plate were removed, leaving the ring of primordial root intact. The peeled bulbs were placed into fresh tap water during the cleaning procedure, so as to protect the primordial from drying. Thereafter, the bulbs were placed into $100 \mathrm{~mL}$ beakers containing $0.5 \%$, $1.0 \%, 2.5 \%, 5 \%$ and $10 \%$ concentrations (v/v, effluent/distilled water) from the effluent. Twelve onion bulbs were set up in each concentration, out of which those 10 presenting the best root growth were selected for analysis of root growth inhibition. Distilled water was used as negative control. The experiment was performed in the dark at $27 \pm 1^{\circ} \mathrm{C}$. Test liquids were changed daily. On the second day $(48 \mathrm{~h}$ ), root tips of two bulbs in the experimental and control groups were fixed in ethanol:glacial acetic acid $(3: 1, \mathrm{v} / \mathrm{v})$, to be then squashed on slides for chromosomal analysis, as previously described (Bakare et al., 2000; Bakare, 2002). On the third day (72 h), measurements were taken of the length of each root from the bulb, by test sample concentration. The percentage of reduction in rootgrowth in relation to the control and $\mathrm{EC}_{50}$ was obtained from the values thus come by. ASTM (1994) minimal statistical guidelines for conducting early seedling growth tests were used in the analysis of measured root length. The effects of the effluent on the morphology of growing roots were also examined.

\section{Sperm morphology assay}

Induction of sperm abnormalities was studied according to Wyrobek et al (1983) and Bakare et al., (2005). Five concentrations of $1 \%, 5 \%, 10 \%, 25 \%$ and $50 \%(\mathrm{v} / \mathrm{v}$, effluent/distilled water) of the effluent were considered together with the positive (cyclophosphamide $20 \mathrm{mg} / \mathrm{kg}$ body weight) and negative (distilled water) controls. A single intraperitoneal (IP) injection of $0.5 \mathrm{~mL}$ of the different test-sample concentrations was administered to the mice daily for 5 consecutive days. The IP route was favored since it is one of the fastest and most efficient means of delivering test-chemicals into test-animals in a short-term-assay. The exposure period was 35 days and 5 mice were treated for each effluent concentration. Sperm was sampled from the caudal epididymes at 5 weeks from the first injection, since spermatogenesis in mice takes 34.5 days until completion (Bartke et al., 1974). The mice were sacrificed by cervical dislocation and their epididymes surgically removed. Two sperm suspensions were prepared from the cauda of each testis by mincing the cauda in physiological saline. Smears were prepared on grease-free slides after staining with $1 \%$ Eosin Y for $45 \mathrm{~min}$. The slides were air-dried and coded for subsequent microscopic examination under oil immersion at 1000x. For each mouse, 800 sperm cells were assessed for morphological abnormalities according to the criteria of Wyrobek and Bruce (1975).

\section{Chromosome aberration assay}

Five groups of mice (3 mice per group) were intraperitoneally exposed to $1 \%, 5 \%, 10 \%, 25 \%$ and $50 \%(\mathrm{v} / \mathrm{v}$, effluent/distilled water) of test-sample concentrations for $48 \mathrm{~h}(1 \mathrm{~mL}$ of each concentration/mouse at $24 \mathrm{~h}$ intervals). Cyclophosphamide $(20 \mathrm{mg} / \mathrm{kg}$ body weight) and distilled water were used as the positive and negative controls, respectively. Chromosome preparations were made as previously described (Preston et al., 1987; Alimba et al., 2006). 
Mice were injected with an aqueous solution of colchicine $(2.5 \mathrm{mg} / \mathrm{kg}$ bw, IP), $2 \mathrm{~h}$ prior to scheduled killing by cervical dislocation. The bone-marrow cells were aspirated into $2.2 \%(\mathrm{w} / \mathrm{v})$ sodium citrate and centrifuged at $2000 \mathrm{rpm}$. for $5 \mathrm{~min}$. The pellets obtained were mixed in an aqueous solution of $\mathrm{KCl}(0.075 \mathrm{M})$ and left for $30 \mathrm{~min}$ at room temperature $\left(29{ }^{\circ} \mathrm{C}\right)$. Cells were re-centrifuged, fixed in cold Carnoy fluid (methanol: glacial acetic acid, 3:1 v/v) and dropped onto clean chilled slides. Finally, the slides were air-dried and stained with 5\% Giemsa (v/v, stock Giemsa stain/distilled water). The mitotic index was calculated by counting the metaphase cells from approximately 3000 cells/concentration and expressed in percent. CAs were scored blind to treatment and at least 50 well spread metaphase cells/mouse were analyzed.

\section{Micronucleus test}

Five groups of mice (4 mice per group, 22-30 g each) were utilized in this assay, considering concentrations $1 \%$, $5 \%, 10 \%, 25 \%$ and $50 \%(\mathrm{v} / \mathrm{v}$, effluent/distilled water) of the test sample as against negative (distilled water) and positive (cyclophosphamide $20 \mathrm{mg} / \mathrm{kg}$ body weight) controls. Each mouse/group was IP exposed to $0.5 \mathrm{~mL}$ of each concentration for $96 \mathrm{~h}$. Bone marrow preparation for micronuclei assessment was according to the procedure of Schmid $(1975,1976)$. Briefly, the animals were sacrificed by cervical dislocation. The femurs were removed from each and bone marrow flushed from the bones with Foetal Bovine Serum (Sigma Aldrich Cheme GmbH, Germany). Cells were centrifuged at $2000 \mathrm{rpm}$ for $5 \mathrm{~min}$ and slides stained with May-Grunwald and Giemsa stains. At least 1000 cells/animal were scored for micronuclei in polychromatic erythrocytes (MNPCE). The differential staining of PCEs (bluish-purple) and normochromatic erythrocytes (NCEs, pinkish-orange), and the relative size of the erythrocytes, are indices for differentiating them.

\section{Statistical analysis}

The SPSS ${ }^{\circledR} 14.0$ statistical package was used for data analysis. Data obtained were expressed as percentage frequency and mean \pm standard error (mean \pm standard deviation in the CA test). Significance at the different dose-level of each assay was tested by using the Dunett t- test. Data on root-growth inhibition were expressed with $95 \%$ confidence limits and ANOVA was used for testing significance. Differences between the negative control-group and individual dose-groups were analyzed at the 0.05 and 0.001 probability levels.

\section{Results}

Physical and chemical characteristics of the pharmaceutical effluent are shown in Table 1. The $\mathrm{pH}$ was 5.70, and there was an offensive odour. Chloride and nitrate levels were very high, likewise with $\mathrm{Zn}, \mathrm{Fe}$ and $\mathrm{Cu}$.
Table 1 - Physico-chemical characteristics of the pharmaceutical effluent assessed for genotoxicity.

\begin{tabular}{|c|c|c|c|}
\hline Parameters* & Effluent sample & FEPA $^{a}$ & USEPA $^{\mathrm{b}}$ \\
\hline Colour & Pale brown & - & - \\
\hline $\mathrm{pH}$ & 5.7 & $6-9$ & $6.5-8.5$ \\
\hline $\mathrm{COD}^{\mathrm{c}}$ & 147.04 & 50 & 410 \\
\hline BOD $^{d}$ & 48.13 & 50 & - \\
\hline $\mathrm{TDS}^{\mathrm{e}}$ & 336 & 2000 & 500 \\
\hline Salinity & 524 & - & - \\
\hline Alkalinity & 120 & 250 & 20 \\
\hline Hardness & 80 & - & $0-75$ \\
\hline Chloride & 5240 & - & 250 \\
\hline Nitrate & 61.3 & 20 & 10 \\
\hline Phosphate & 42 & 5.0 & - \\
\hline $\mathrm{NH}_{3}$ & 23.4 & 0.01 & 0.02 \\
\hline $\mathrm{Cd}$ & 0.002 & 0.01 & 0.005 \\
\hline $\mathrm{Cr}$ & 0.01 & 0.05 & 0.10 \\
\hline $\mathrm{Cu}$ & 1.02 & 0.01 & 1.0 \\
\hline $\mathrm{Fe}$ & 1.80 & 0.3 & 0.30 \\
\hline $\mathrm{Mn}$ & 0.46 & 0.05 & 0.05 \\
\hline $\mathrm{Ni}$ & 0.020 & 0.05 & - \\
\hline $\mathrm{Zn}$ & 10.20 & 5.0 & 5.0 \\
\hline
\end{tabular}

*All values are in $\mathrm{mg} / \mathrm{L}$ except $\mathrm{pH}$ and salinity (ppt.). ${ }^{\mathrm{a}} \mathrm{FEPA}$ : Federal Environmental Protection Agency (2001). ' USEPA: United States Environmental Protection Agency (1989). ${ }^{\circ}$ COD: Chemical oxygen demand. ${ }^{\mathrm{d}}$ BOD: Biochemical oxygen demand. ${ }^{\mathrm{e}}$ TDS: Total dissolved solid.

\section{Allium cepa assay}

Table 2 shows the results from macroscopic and microscopic analysis of treated Allium cepa roots. Root growth attained a maximum in the control (distilled water). Here, the roots were whitish in color, elongated and straight, with no morphological deformities. At the various concentrations of the test sample, there was a gradual statistically significant $(p<0.05)$ concentration-dependent inhibition of root growth. The least mean root growth and the highest mean root growth were obtained at the $5 \%$ and $0.5 \%$ concentrations, respectively. There was no root growth at a concentration of $10 \%$. Morphological deformities such as very short, bent, spiral and crochet-like roots were also observed at tested concentrations, especially at a concentration of $5 \%$. The $\mathrm{EC}_{50}$ value obtained from the $\%$ inhibition value was $1.82 \%$. Under microscopic analysis, there was a concentration-dependent reduction in mitotic index, compared to the negative control value of $33.5 \%$, in all concentrations. Chromosomal aberrations (Figure 1a-c) were induced in all the different concentrations, all (except at the $0.5 \%)$ being statistically significant $(\mathrm{p}<0.05)$.

\section{Chromosome aberration assay}

Exposure of mice to the effluent sample for $48 \mathrm{~h}$ inhibited MI in bone-marrow cells in a dose-dependent manner, but this was only statistically significant $(p<0.05)$ at 
Table 2 - Inhibitory and cytological effects of the pharmaceutical effluent on Allium cepa root.

\begin{tabular}{lccccc}
\hline \multicolumn{5}{c}{ Root growth inhibition (macroscopic analysis) } \\
\hline Conc. (\%, v/v) & $\begin{array}{l}\text { Average root length for } \\
\text { each bulb (range in cm) }\end{array}$ & Mean \pm SE & Growth in \% of control & Percent inhibition & $95 \%$ confidence limit \\
\hline Distilled water & $3.2-4.8$ & $3.95 \pm 0.21$ & - & 0 & 0.38 \\
0.5 & $2.6-4.3$ & $3.58 \pm 0.20$ & 90.6 & 37.5 & 0.44 \\
1.0 & $2.0-3.7$ & $2.47 \pm 0.11$ & 62.5 & 64.2 & 0.60 \\
2.5 & $0.5-2.0$ & $0.23 \pm 0.02$ & 35.8 & 84.7 & 0.65 \\
5.0 & $0.2-0.4$ & $0.21 \pm 0.04$ & 15.3 & - & 0.43 \\
10.0 & No root growth & - & - & - \\
\hline
\end{tabular}

\begin{tabular}{|c|c|c|c|c|c|c|}
\hline \multicolumn{7}{|c|}{$\mathrm{EC}_{50}=1.82 \%$} \\
\hline \multicolumn{7}{|c|}{ Chromosomal aberrations (microscopic analysis) } \\
\hline${ }^{*}$ Conc. $(\%, v / v)$ & N. of dividing cells & $\begin{array}{c}\text { Mitotic } \\
\text { index (MI) }\end{array}$ & $\begin{array}{l}\text { N. of sticky } \\
\text { chromosomes }\end{array}$ & $\begin{array}{l}\text { N. of scattered/ } \\
\text { disoriented } \\
\text { chromosomes }\end{array}$ & $\begin{array}{l}\text { N. of chromosomes } \\
\text { with spindle } \\
\text { disturbance }\end{array}$ & $\begin{array}{c}\text { Frequency of } \\
\text { aberrant cells (\%) }\end{array}$ \\
\hline Distilled water & 1339 & 33.5 & - & - & - & - \\
\hline 0.5 & 1032 & 25.8 & 3 & 2 & 4 & 0.87 \\
\hline 1.0 & 588 & $17.2^{+}$ & 3 & 4 & 6 & $1.89^{+}$ \\
\hline 2.5 & 370 & $9.25^{+}$ & 5 & 7 & 7 & $5.14^{+}$ \\
\hline 5.0 & 158 & $3.95^{+}$ & 6 & 8 & 12 & $16.46^{+}$ \\
\hline 10.0 & - & - & - & - & - & - \\
\hline
\end{tabular}

* 4000 cells (4 slides) per concentration and the control.

+ Values are significantly different from the control at $\mathrm{p}<0.05$ (ANOVA).

the 10,25 and $50 \%$ concentrations of the test sample (Table $3)$. Different types of dose-dependent and statistically significant $(\mathrm{p}<0.05)$ CAs were observed (Figure 2a-d).

\section{Micronucleus test}

Figure 3 shows the micronuclei induced in the bone marrow cells after exposure of mice to the test sample. Compared with the negative control, there was a statistically significant $(p<0.001)$, dose- dependent increase in $\mathrm{MN}$ at all concentrations, except 1\% and 5\% (Figure 4). The dose-response equation for this effect is $\mathrm{y}=7.45+1.65 \mathrm{x}(\mathrm{y}=0.99)$.

The positive control induced a significant induction of $\mathrm{CA}$ and $\mathrm{MN}$ in positive control groups.

\section{Sperm morphology assay}

Figure 5 (a-g) shows the different types of abnormal sperm cells observed, 5 weeks from the $1^{\text {st }}$ day of exposure of male mice to the test pharmaceutical-effluent. The frequency of abnormal sperm cells in the negative control was $9.85 \%$. There were $27.8 \%, 31.0 \%, 33.3 \%, 40.6 \%$ and $47.2 \%$ of abnormal sperm cells at the tested concentrations of $1 \%, 5 \%, 10 \%, 25 \%$ and $50 \%$, respectively. This induction of abnormalities was statistically significant $(\mathrm{p}<0.05)$ and concentration-dependent at all concentrations except at $1 \%$. Generally speaking, sperm with wrong-angled hooks (Figure $5 \mathrm{~b}$ ) were the most prominent $(26.1 \%)$, whereas double-tailed sperm cells (Figure 5h) were very few in number $(0.6 \%$ occurrence) .

\section{Discussion}

Industrial discharge is recognized as one of the major sources of toxic chemicals in the environment. In the present study, the genotoxicity and mutagenicity of a pharmaceutical effluent was assessed by using a battery of in vivo assays in plant and animal systems. The results of the

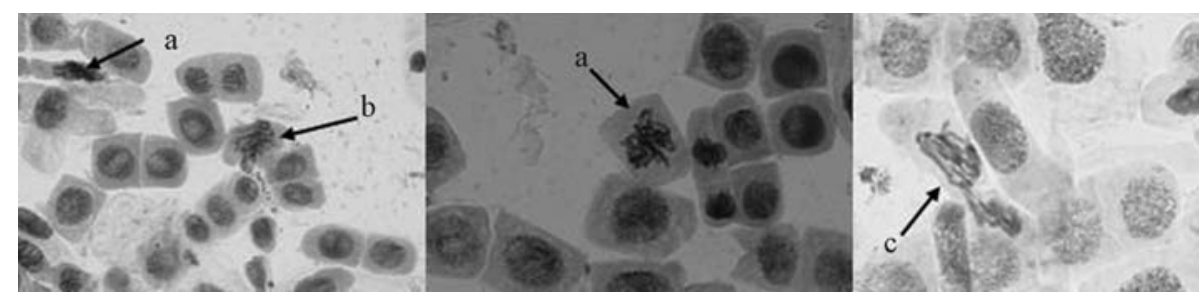

Figure 1 - Chromosomal aberrations (arrowed) induced in Allium cepa root tips by the pharmaceutical effluent. (a) sticky chromosomes, (b) chromosomes with spindle disturbance, (c) disoriented chromosomes. Magnification 1000x. 


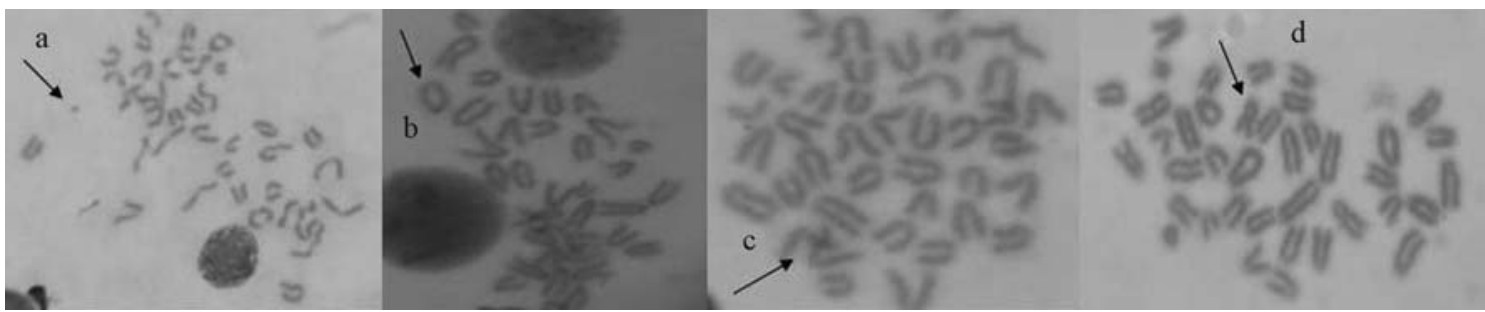

Figure 2 - Chromosomal aberrations (arrowed) induced in bone marrow cells of mice exposed to the pharmaceutical effluent. (a) chromatid break, (b) ring chromosome, (c) chromatid exchange, (d) dicentric chromosome. Magnification 1000x.

Table 3 - Chromosome aberrations (CAs) induced in bone marrow cells of mice exposed to different concentrations of the pharmaceutical effluent.

\begin{tabular}{lccccc}
\hline Conc. $(\%, \mathrm{v} / \mathrm{v})$ & N. of cells at metaphase & MI \pm SD & Total n. of CA & Mean of CA \pm SD & Frequency of aberration \\
\hline Distilled water & 128 & $4.27 \pm 2.08$ & 4 & $1.33 \pm 0.58$ & 2.7 \\
1.0 & 123 & $4.1 \pm 1.0$ & 22 & $10.7^{*} \pm 0.58$ & 14.7 \\
5.0 & 112 & $3.7 \pm 1.53$ & 39 & $13.0^{*} \pm 2.31$ & 26.0 \\
10 & 104 & $3.5^{*} \pm 2.52$ & 41 & $13.7^{*} \pm 3.06$ & 27.3 \\
25 & 95 & $3.2 * \pm 3.21$ & 48 & $16.0^{*} \pm 4.58$ & 32.0 \\
50 & 87 & $2.9^{* *} \pm 1.0$ & 53 & $17.7^{*} \pm 5.7$ & 35.3 \\
Cyclophosphamide $^{\#}$ & 71 & $2.4^{* *} \pm 2.65$ & 59 & $19.7 * * \pm 1.52$ & 43.3 \\
\hline
\end{tabular}

${ }^{*} \mathrm{p}<0.05,{ }^{* *} \mathrm{p}<0.001$ : levels of significance of chromosome damage in bone-marrow cells of mice $v s$. distilled water (negative control). MI: Mitotic Index (3000 cells/concentration). ${ }^{*}: 20 \mathrm{mg} / \mathrm{kg}$ body weight.

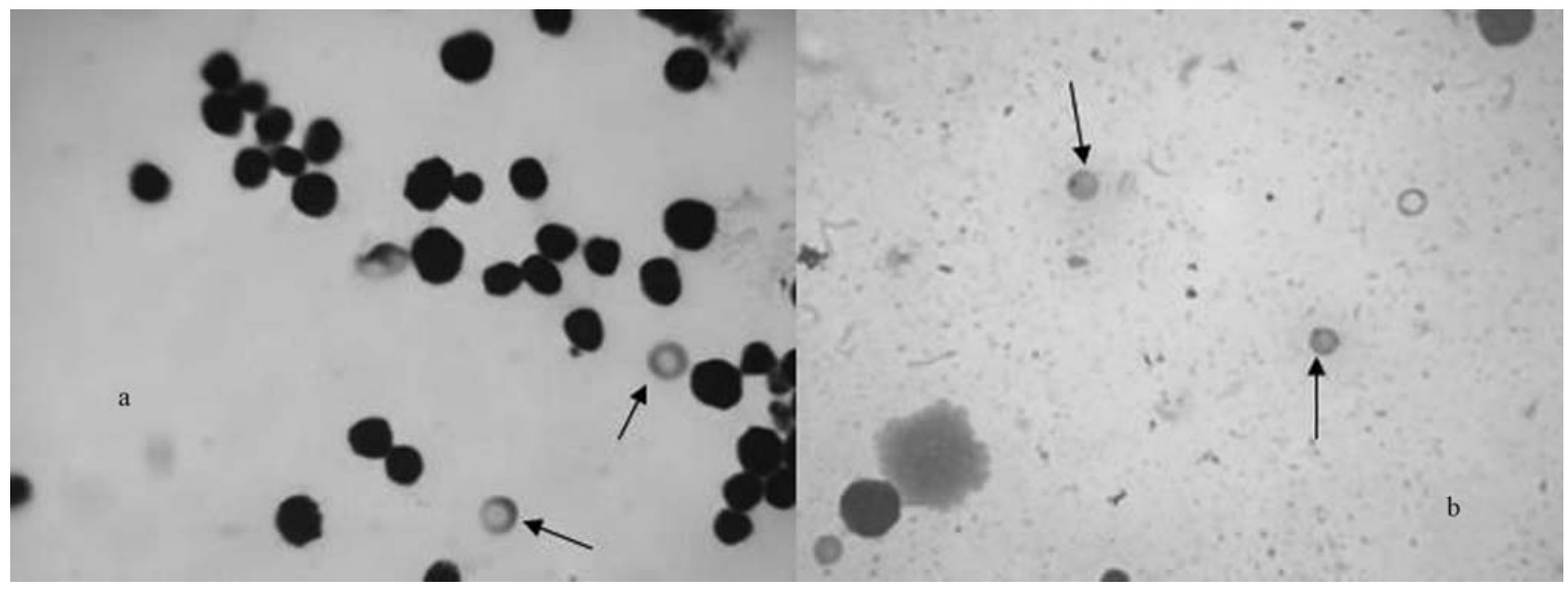

Figure 3 - Micronuclei (MN) induced in mice exposed to the pharmaceutical effluent (a) Normal Polychromatic erythrocyte (b) Micronucleated Polychromatic Erythocyte (MNPCE). Magnification 1000x.

physico-chemical characteristics of the effluent showed the presence of certain sample-constituents at concentrations beyond the permitted limits set by international regulatory authorities (Table 1). Heavy metal analysis of effluentsamples showed the presence of $\mathrm{Cu}, \mathrm{Ni}, \mathrm{Cr}, \mathrm{Cd}, \mathrm{Mn}, \mathrm{Al}, \mathrm{Fe}$, and $\mathrm{Zn}$ at various concentrations. These metals have the potential to induce mutation and cancer in living cells. A mixture of these may result in synergistic chemical combinations that are more harmful than the individual constituent itself. Studies in experimental animals indicate that $\mathrm{Ni}$ (Haugen et al., 1994) and Cd (Elinder and Jarup, 1996) are carcinogenic. Hexavalent $\mathrm{Cr}$ was reported to have induced chromosomal aberrations, and micronuclei and singlestrand breaks in mammalian cells (Wise et al., 2002), besides gene mutation in bacteria (DeFlora et al., 1990). Trivalent Fe was also reported as having been responsible for the high level of micronuclei in newt larvae (Godet et al., 1996). The exposure of mice to $\mathrm{Zn}$ results in both single-strand breaks in DNA, as measured by the comet assay (Banu et al., 2001), as well as chromosomal aberrations (Gupta et al., 1991). Ni is known to produce highly selective damage to heterochromatin (Costa et al., 1994). It has 


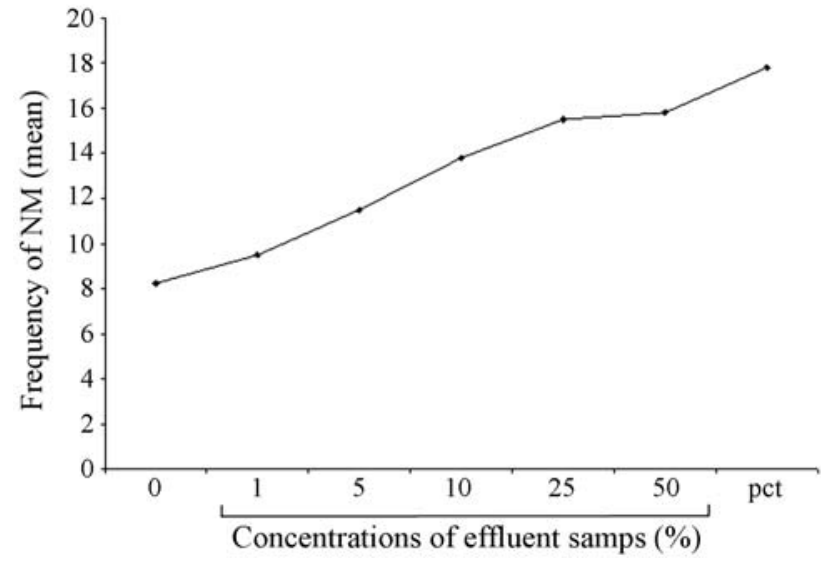

Figure 4 - Frequency of MN induced in bone-marrow cells of mice exposed to the pharmaceutical effluent Zero: negative control (distilled water) Pct. Positive control (cyclophosphamide $20 \mathrm{mg} / \mathrm{kg}$ body weight).

also been reported that $\mathrm{Cd}, \mathrm{Cu}$ and $\mathrm{Fe}$ gave rise to reactive oxygen species in eukaryotic systems (Ghio et al., 2002; Radetski et al., 2004). The constituents analyzed herein do not represent all, or even most, of the chemicals that could have been included in the test-sample. An effluent is a complex mixture of organic and inorganic chemicals, and of many unidentified toxicants known as non-conventional pollutants (NCPs), all of which may pose risks of an unknown magnitude to humans.

From data obtained through bioassays, it is shown that the tested effluent is cytotoxic, mutagenic and genotoxic. The results of the A. cepa assay are indicative of a linear relationship between macroscopical (root-growth inhibition) and microscopical (genotoxicity) parameters. The macroscopic effect appears to be the most sensitive parameter, since any genotoxic effect manifest in a test sample, either directly or indirectly, is likely to result in inhibition of growth (Fiskesjo, 1997). The $\mathrm{EC}_{50}$ value indicated that the tested sample is highly toxic, with the highest tested concentration $(10 \%)$ totally inhibiting root-growth in the treated bulbs. Microscopic examination allowed for assessing chromosome damage and cell-division disturbances, thus providing additional information regarding severity or mechanism of the toxic effect or of potential mutagenicity. In A. серa, whenever chromosome aberrations occurred, there were almost always certain growth restrictions (Fiskesjo, 1997). This became evident in this study, and corroborates previous observations on this assay, when done in our laboratory (Bakare and Wale-Adeyemo, 2004; Babatunde and Bakare, 2006). Similar observations were also reported on dye wastewater (Somashekar and Gowda, 1983), sugar-cane factory wastewater (Mishra, 1993) and carbonaceous sugar-mill effluents (Kumar, 2000), when using the $A$. cepa test.

In the sperm morphology assay, the criteria for a positive response were satisfied: there was an increase in abnormal sperm morphology to at least double the negative control level (at all treatment levels). There was also evidence of a concentration-dependent increase in the number of aberrant sperm cells. Sperm morphology tests provide a direct measure of the quality of sperm production in chemically treated animals. Studies evaluating the genetic consequences of chemically induced sperm changes have mainly focused on understanding the genetic basis of chemically shaped abnormalities in mice. A number of lines of evidence suggest that an induced change in sperm morphology is reflected by genetic damage in the male germ cell (Topham, 1980). Wyrobek et al. (1983) also noted that when male germ cells are exposed in vivo to a test sample, a positive result demonstrates the sample ability to damage spermatogenesis. Our observations are in accordance with those of Muller and Kasper (2000) who showed that pharmaceuticals are not only capable of inducing abnormal sperm cells, but are also carcinogenic in mice. Similarly, Caldwell (1993) concluded that pharmaceutical compounds are potentially genotoxic to mouse sperm cells, and therefore suggested that the waste from such products may be equally dangerous. Thus, the sperm abnormalities observed herein are an indication that the effluent chemical constituents, in fact, exerted an effect on sperm from treated spermatogonial cells. This goes to show that the effluent constituents, in this case, were capable of interacting with the genetic processes involved in spermatogenesis in mice.

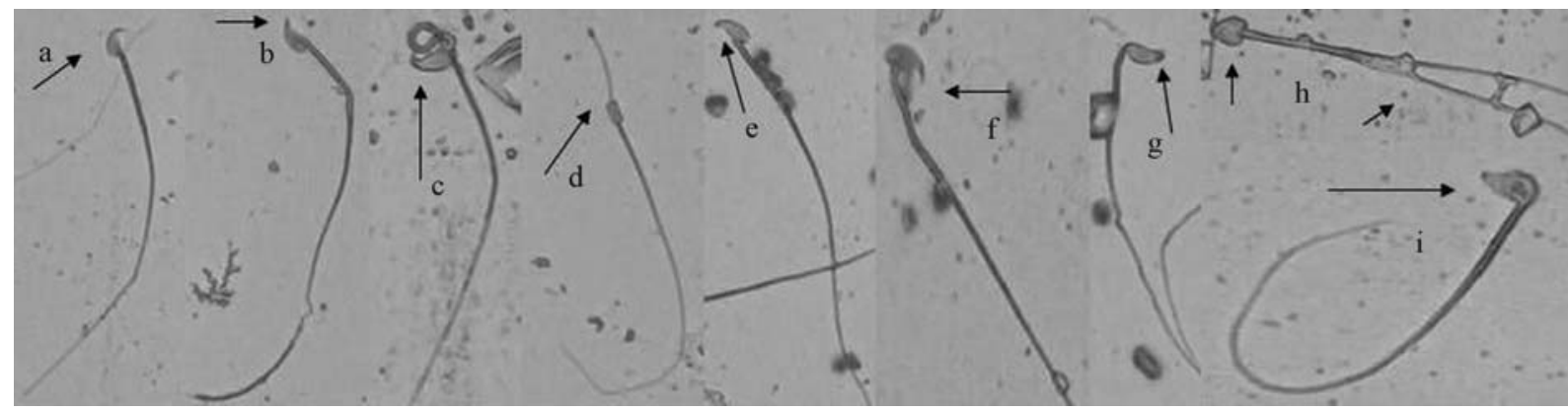

Figure 5 - Abnormal sperm cells induced in mice exposed to different concentrations of the pharmaceutical effluent (a) normal sperm cell, (b) wrong-angled hook, (c) folded sperm, (d) pin head, (e) very short hook, (f) wrong tail attachment, (g) No hook, (h) double-tailed sperm with amorphous head, (i) amorphous head. Magnification 800x. 
Results from the MN and CA assays showed that pharmaceutical effluents caused a decrease in MI, and induced high CA and MNPCE frequency in mouse bonemarrow cells. Marked inhibition of MI indicates testeffluent cytotoxic potentiality in mice. In the test-sample, the possible mitotic inhibition mechanism is the most likely action in microtubule functioning and/or formation (Stehrer-Schmid and Wolf, 2005). The induction of various types of structural CA elicits the clastogenic potential of pharmaceutical effluents, which, through long-term exposure, can cause somatic mutation. Increased frequency in the occurrence of acentric type aberrations indicates microtubule distortion, similar to that observed in the A. серa assay in the form of chromosomes with disturbed spindle. A possible mechanism for the induction of anomalies in mouse bone-marrow cells is that the effluent was absorbed into the cells and caused change in $\mathrm{pH}$ within and outside cells, which might affect the activities of enzymes and the structure of DNA (Meng et al., 2002). Other possible mechanisms might have been the formation of free radicals, either through auto-oxidation, pharmacodynamics or enzyme-catalyzed oxidation of electrophilic components of the effluent. Free radicals, endogenously generated on exposure to the effluent, could react with the lipid content of the cell membrane, thus resulting in lipid peroxidation in the tissues, thereby causing breakage of the DNA chain by oxidating the base component of the membrane. The free radicals could also have reacted with those proteinenzymes involved in the DNA repair mechanism, the alteration of repair enzyme activity resulting in increased frequency in DNA damage. It is important to note that the reactions of DNA and the free radicals, especially the reactive oxygen species, result in the production of covalently modified bases known as DNA adducts, which are mutagenically potent contributors to the aetiology of genetic diseases (Marnett and Burcham, 1993).

The CA and MN assays were primarily devised for evaluating the ability of test-chemicals to induce structural and/or numerical chromosomal damage. There is a correlation between the two assays. Generally, micronuclei are forms resulting from the aggregation of whole chromosomal or chromosome/chromatid fragments, aberrations and disturbances in the mitotic process (Grover and Kaur, 1999). Both types of damage are associated with the appearance and/or progression of tumours, and adverse reproductive and developmental outcomes (Krishna and Hayashi, 2000).

The genotoxicity of industrial effluents has been extensively assessed (Houk and DeMarini, 1988; Houk, 1992; Snyder and Green, 2001; Babatunde and Bakare; 2006; Siddique et al., 2008). Our study provides additional and original in vivo information on existing in vitro studies on the genotoxicity of pharmaceutical effluents. The mechanism of induction of genetic damage in the four assays may be as previously described for similar complex mix- tures (Alimba et al., 2006; Li et al, 2006a; 2006b; Bakare et $a l ., 2007)$. Our findings are of importance as chemically induced genetic damage has been implicated in the aetiology of many genetic diseases. The increased genetic damage caused by industrial effluent/waste mixtures in eukaryotic cells indicates a potential genetic hazard. This is of great importance to public health, seeing that environmental waste management in many developing nations is wholly inadequate.

\section{Acknowledgments}

We thank the head of the Department of Zoology, University of Ibadan, Nigeria and Professor Alok Dhawan of the Indian Institute of Toxicology Research, Lucknow, India for assisting with facilities.

\section{References}

Alimba CG, Bakare AA and Latunji CA (2006) Municipal landfill leachates induced chromosome aberrations in rat bone marrow cells. Afr J Biotech 5:2053-2057.

American Public Health Association (1998) Standard Methods for the Examination of Water and Wastewater. 20th ed. American Public Health Association, Washington DC, $1220 \mathrm{pp}$.

ASTM (1994) Standard practice for conducting early seedling growth tests 1. American Society for Testing and Material Designation E 1598-94:1493-1499.

Bakare AA (2002) In vivo mutagenic and acute effects of leachate from three wastes dump sites in South-West Nigeria. PhD Thesis, University of Ibadan, Nigeria.

Babatunde BB and Bakare AA (2006) Genotoxicity screening of wastewaters from Agbara industrial estate, Nigeria evaluated with the Allium test. Poll Res 25:227-234.

Bakare AA and Wale-Adeyemo AR (2004) The potential mutagenic and cytotoxic effects of leachates from domestic wastes and Aba-Eku landfill, Nigeria on Allium cepa. J Nature Environ Poll Technol 3:455-462.

Bakare AA, Mosuro AA and Osibanjo O (2000) Effect of simulated leachate on chromosomes and mitosis in roots of Allium cepa (L). J Environ Biol 21:263-271.

Bakare AA, Mosuro AA and Osibanjo O (2005) An in vivo evaluation of induction of abnormal sperm morphology in mice by landfill leachates. Mutat Res 582:28-34.

Bakare AA, Pandey AK, Bajpayee M, Bhargav D, Chowdhuri DK, Singh KP, Murthy RC and Dhawan A (2007) DNA damage induced in human peripheral blood lymphocyte by industrial solid waste and municipal sludge leachates. Environ Mol Mutagen 48:30-37.

Banu BS, Devi KD, Maliboob M and Jamil K (2001) In vivo genotoxic effect of zinc sulfate in mouse peripheral blood leukocytes using comet assay. Drug Chem Toxicol 24:6373.

Bartke AJ, Weir A, Mathison P, Roberson C and Dalterio S (1974) Testicular function in mouse strains with different age of sexual maturation. J Hered 65:204-208.

Caldwell J (1993) Perspective on the usefulness of the mouse lymphoma assay as an indicator of a genotoxic carcinogen; ten compounds which are positive in the mouse lymphoma as- 
say but are not genotoxic carcinogens. Terat Carcinogen Mutagen 13:185-190.

Christensen TH (1998) Pharmaceuticals in the environment - A human risk? Regulat Toxicol Pharmacol 28:212-221.

Costa M, Salnikow K, Consentino S, Klein CB, Huang X and Zhaung Z (1994) Molecular mechanism of nickel carcinogenesis. Environ Health Perspect 102:127-130.

DeFlora S, Begnasco M, Serra D and Zanacchi P (1990) Genotoxicity of chromium compounds. Mutat Res 238:99-178.

Elinder CG and Jarup L (1996) Cadmuim exposure and health risks: Recent findings. Ambio 25:370-373.

Federal Environmental Protection Agency (2001) Federal Ministry of Environment National Guidelines and Standards for Water in Nigeria, Lagos, Nigeria; Federal Environmental Protection Agency.

Fiskesjo G (1997) Assessment of a chemical's genotoxic potential by recording aberration in chromosomes and cell divisions in root tips of Allium cepa. Environ Toxicol Water Qual 9:235-241.

Ghio AJ, Silbajoris R, Carson JL and Samet JM (2002) Biologic effects of oil fly ash. Environ Health Perspect 110:89-94.

Godet F, Babut M, Burnal D, Verler AM and Vasscur P (1996) The genotoxicity of iron and chromium in electroplating effluents. Mutat Res 370:19-28.

Grover IS and Kaur S (1999) Genotoxicity of wastewater samples from sewage and industrial effluent detected by the Allium root anaphase aberration and micronucleus assays. Mutat Res 426:183-188.

Gupta T, Talukder G and Sharma A (1991) Cytotoxicity of zinc chloride in mice in vivo Biol Trace Elem Res 30:95-101.

Haugen A, Maehle L, Mollerup S, Rivedal E and Ryberg D (1994) Nickel induced alteration in human renal epithelial cells. Environ Health Perspect 102:117-118.

Houk VS (1992). The genotoxicity of industrial wastes and effluents: A review. Mutat Res 227:91-138.

Houk VS and DeMarini DM (1988) Use of the microscreen phage-induction assay to assess the genotoxicity of 14 hazardous industrial wastes. Environ Mol Mutagen 11:13-29.

Jonathan PB and Nicolaos V (2005) Household disposal of pharmaceuticals as a pattern for aquatic contamination in the United Kingdom. Environ Health Perspect 113:1705-1711.

Krishna G and Hayashi M (2000) In vivo rodent micronucleus assay: Protocol, conduct and data interpretation. Mutat Res 455:155-166.

Kumar A (2000) Carbonaceous sugar mill effluent retards growth and yield of Hordeum vulgare 1B65. Adv Plant Sci 13:93$-96$.

Li G, Sang N and Guo D (2006a) Oxidative damage induced in hearts, kidneys and spleens of mice by landfill leachate. Chemosphere 65:1058-1063.

Li G, Sang N and Wang Q (2006b) Oxidative damage induced in brains and livers of mice by landfill leachate. Ecotox Environ Saf 65:134-139.

Marnett LJ and Burcham P (1993) Endogenous DNA adducts: Potential and paradox. Chem Res Toxicol 6:771-785.

McGeorge LJ, Loius JB, Atherholt TB and McGarity GJ (1985) Mutagenicity analyses of industrial effluents: Results and considerations for integration into water pollution control programmes. In: Waters MD, Sandhu SS, Lewtas J, Claxton L, Strauss G and Nesnow S (eds) Short-Term Bioassays in the Analysis of Complex Environmental Mixtures, IV. Plenum Press, New York, pp 247-268.

Meng ZQ, Sang N and Zhang B (2002) Effects of derivatives of sulfur dioxide on micronuclei formation in mouse bone marrow cells in vivo Bull Environ Contam Toxicol 69:257-264.

Mishra K (1993) Cytotoxic effects of distillary waste on Allium Cepa L. Bull Environ Contam Toxicol 50:199-204.

Møller MA, Bjørseth A and Houk VS (1985) Chemical separation and in situ mutagenicity testing. In: Zimmermann FK and Taylor-Mayer RE (eds) Mutagenicity Testing in Environmental Pollution Control. J. Wiley and Sons, New York, pp 47-67.

Muller L and Kasper P (2000) Human biological relevance and the use of threshold arguments in regulatory genotoxicity assessment: Experience with pharmaceuticals. Mutat Res 464:19-34.

Preston RJ, Kean BJ and Galloway S (1987) Mammalian in vivo cytogenetic assays: Analysis of chromosome aberrations in bone-marrow cells. Mutat Res 198:157-165.

Radetski CM, Ferrari B, Cotelle S, Masfaraud JF and Ferard JF (2004) Evaluation of the genotoxic, mutagenic and oxidant stress potentials of municipal solid waste incinerator bottom ash leachates. Sci Total Environ 333:209-216.

Sanchez PS, Sato MIZ, Paschoal CMRB, Alves MN, Furlan EV and Martins MT (1988) Toxicity assessment of industrial effluents from S. Paulo State, Brazil, using short-term microbial assays. Tox Assess 3:55-80.

Schmid W (1975) The micronucleus test. Mutat Res 31:9-15.

Schmid W (1976) The micronucleus test for cytogenetic analysis. In: Hollander A (ed) Chemical Mutagens, Principles and Methods for Their Detection, v. 4. Plenum Press, New York, pp 31-53.

Siddique HR, Sharma A, Gupta SC, Murthy RC, Dhawan A, Saxena DK and Chowdhuri DK (2008) DNA damage induced by industrial solid-waste leachates in Drosophila melanogaster: A mechanistic approach. Environ Mol Mutagen 49:206-216.

Snyder RD and Green JW (2001) A review of the genotoxicity of marketed pharmaceuticals. Mutat Res 488:151-169.

Somashekar RK and Gowda MTG (1983) Cellular damage induced by dye industry wastewater in Allium cepa. Curric Sci 52:317-319.

Stehrer-Schmid P and Wolf HU (1995) Genotoxic evaluation of three heterocyclic $N$-methylcarbanate pesticides using the mouse bone marrow micronuleus assay and Saccharomyces cerevisae strain D and D6 M. Mutat Res 345:111-125.

Topham JC (1980) Chemically induced transmissible abnormalities in sperm-head shape. Mutat Res 70:109-114.

United States Environmental Protection (1976) Pharmaceutical industry: Hazardous waste generation, treatment and disposal. USEPA, Washington, DC., pp 44.

United State Environmental Protection Agency (1996) Acid digestion of sediments, sludges and soil method - 3050B. USEPA, Washington, DC.

Wise JP, Wise SS and Little JE (2002) The cytotoxicity and genotoxicity of particulate and soluble hexavalent chromium in human lung cells. Mutat Res 517:221-229.

Wyrobek AJ and Bruce WR (1975) Chemical induction of sperm abnormalities in mice. Proc Natl Acad Sci USA 72:44254429. 
Wyrobek AJ, Gordon LA, Burkhart JG, Francis MW, Kapp Jr RW, Letz G, Malling HG, Topham JC and Whorton MD (1983) An evaluation of the mouse sperm morphology test and other sperm tests in non-human mammals. A report of the United States Environmental Protection Agency Gene Tox Programme. Mutat Res 115:1-72.

\section{Internet Resources}

United States Environmental Protection Agency (1989) www.epa.gov/safewater/mcl.html (April 22, 2008).
Velagaleti R and Burns PK (2006) The Industrial ecology of pharmaceutical raw materials and finished products with emphasis on supply chain management activities. http://www.epa.gov/esd/chemistry/ppcp/images/ecology.pdf (September 1, 2006).

Associate Editor: Catarina S. Takahashi

License information: This is an open-access article distributed under the terms of the Creative Commons Attribution License, which permits unrestricted use, distribution, and reproduction in any medium, provided the original work is properly cited. 